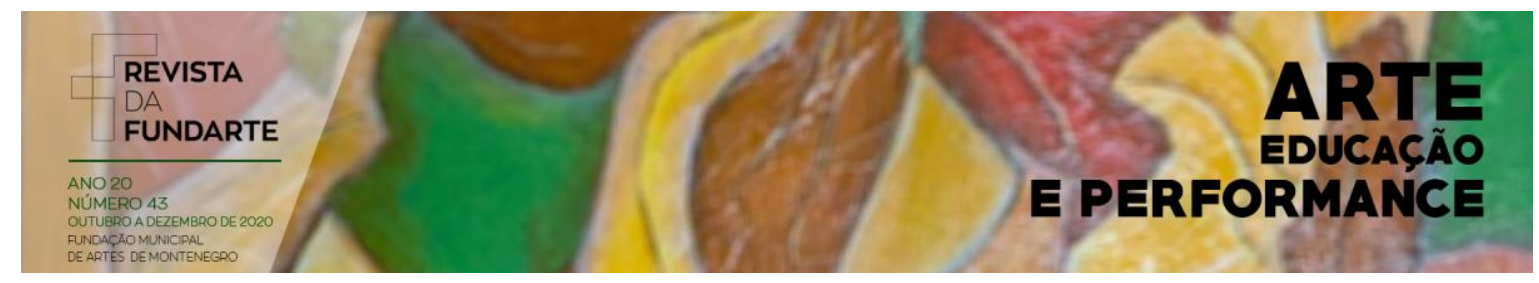

OS CAMINHOS DO ENSINO DE ARTE EM ALGUMAS ESCOLAS PÚBLICAS DO EXTREMO OESTE DE SANTA CATARINA

\author{
Noeli Moreira
}

DOI: http://dx.doi.org/10.19179/2F2319-0868/2F680

MOREIRA, Noeli. Os caminhos do ensino de arte em algumas escolas públicas do extremo oeste de Santa Catarina. Revista da FUNDARTE. Montenegro, p.01-21, ano 20, ํㅡ 43, outubro/dezembro de 2020.

Disponível em: http://.seer.fundarte.rs.gov.br/index.php/revistadafundarte/index> 20 de dezembro de 2020. 


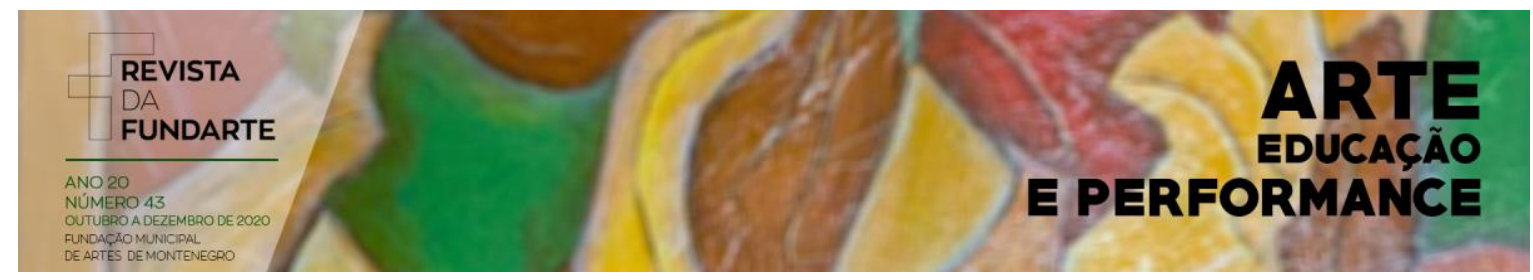

\title{
OS CAMINHOS DO ENSINO DE ARTE EM ALGUMAS ESCOLAS PÚBLICAS DO EXTREMO OESTE DE SANTA CATARINA
}

\author{
Noeli Moreira $^{1}$
}

\begin{abstract}
Resumo: O presente artigo traz alguns resultados sobre o universo do professor de Arte das escolas públicas de municípios do Extremo Oeste Catarinense. Esses dados foram coletados no segundo semestre de 2017, nos municípios de Barra Bonita, Bandeirante, Belmonte, Descanso, Guaraciaba, Paraíso e São Miguel do Oeste. O principal objetivo foi identificar as realidades profissionais dos professores de Arte do ensino fundamental, localizando-os na região, através das instituições de ensino e das redes sociais. A partir desse trabalho, concluímos que quando sabemos da realidade do nosso entorno, as ações para a valorização da atuação docente são significativas e contribuem para a melhoria nos processos educacionais da região.
\end{abstract}

Palavras-chave: Identificação; Cotidiano docente; Valorização.

\section{THE PATHS OF ART TEACHING IN SOME PUBLIC SCHOOLS IN THE FAR WEST OF SANTA CATARINA}

\begin{abstract}
The present article brings some results about the universe of Art teacher of the public schools of municipalities of the Far West of Santa Catarina. These data were collected in the second half of 2017 in the municipalities of Barra Bonita, Bandeirante, Belmonte, Descanso, Guaraciaba, Paraíso and São Miguel do Oeste. The main objective was to identify the professional realities of Art teachers of elementary education, locating them in the region, through educational institutions and social media. From this work we conclude that when we know the reality of our surroundings, the actions for the valorization of the teaching performance are significant and contribute to the improvement in the educational processes of the region.
\end{abstract}

Keywords: Identification; Daily teaching; Valorization.

\footnotetext{
${ }^{1}$ Mestra em Artes Visuais, na linha de pesquisa do Ensino das Artes Visuais do programa de PósGraduação em Artes Visuais- PPGAV/UDESC, conclusão em 31 de julho de 2019. Possui graduação em Educação Artística Habilitação em Artes Plásticas pela Universidade do Oeste de Santa Catarina, Campus de São Miguel do Oeste (2003). Com as seguintes Especializações: Arte e Cultura: Linguagens na Educação pela Universidade Regional Integrada do Alto Uruguai e das Missões- URI (2007) e Arteterapia, Educação e Saúde pela Universidade do Oeste de Santa Catarina Campus de São Miguel do Oeste- UNOESC (2010). Já atuou na educação infantil, ensino fundamental, ensino médio e ensino superior. Atualmente é docente do Ensino Básico, Técnico e Tecnológico do IFSCInstituto Federal de Santa Catarina- Campus de São Miguel do Oeste, desde maio de 2011.
}

MOREIRA, Noeli. Os caminhos do ensino de arte em algumas escolas públicas do extremo oeste de Santa Catarina. Revista da FUNDARTE. Montenegro, p.01-21, ano 20, ํㅡ 43, outubro/dezembro de 2020.

Disponível em: http://.seer.fundarte.rs.gov.br/index.php/revistadafundarte/index> 20 de dezembro de 2020. 


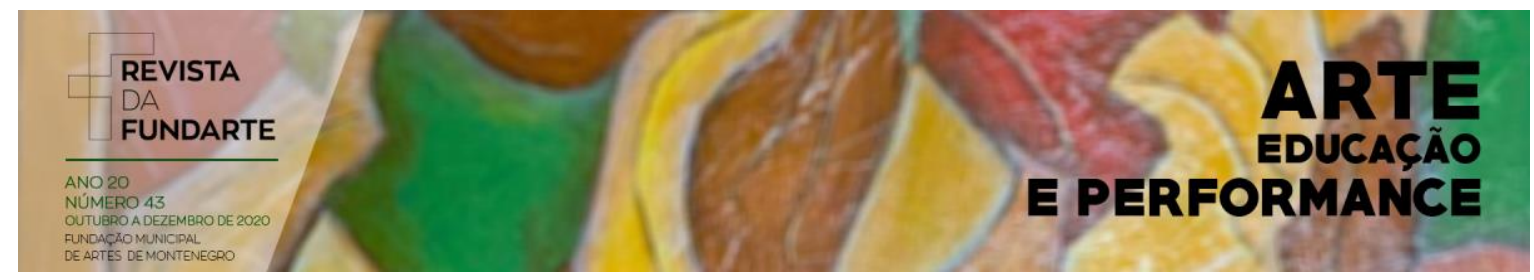

\title{
Introdução
}

\begin{abstract}
"Não há ensino sem pesquisa e pesquisa sem ensino. Esses que-fazeres se encontram um no corpo do outro. Enquanto ensino continuo buscando, reprocurando. Ensino porque busco, porque indaguei, porque indago e me indago. Pesquiso para constatar, constatando, intervenho, intervindo, educo e me educo. Pesquiso para conhecer e o que ainda não conheço e comunicar ou anunciar a novidade".
\end{abstract}

(Paulo Freire, 1996)

Ser docente é inquietar-se em seu ofício. É ser curioso sobre as questões que permeiam o cotidiano. Pensar sobre isso nos remete às possibilidades da pesquisa como instrumento que auxilia no movimento de refletir, compreender, analisar, questionar, criar e transformar a realidade. E é nesse cotidiano que as questões de ensinar e aprender são companhias diárias ao processo educacional.

A atividade docente é permanente e requer respostas diárias sobre a atuação e o comprometimento no ato de ensinar, criando um movimento contínuo de possibilidades para a sua construção (FREIRE, 1996 p. 21). Porém percebemos que a realidade das respostas depende do que é questionado. Participar da realidade escolar hoje é um desafio a todos os seus integrantes. Estar nesse espaço de conhecimento e transformação constante, significa questionar-se sobre sua atuação, identificando as possibilidades e alternativas para a melhoria da escola e da aprendizagem dos alunos, onde o caminho de ensinar e aprender são ações, tanto dos professores, alunos e toda a comunidade escolar; desafios de todos, especialmente neste contexto do professor de arte.

É neste contexto que a presente pesquisa preliminar se justifica, pois para compreender o percurso dos docentes de Arte é preciso conhecê-los, identificando os aspectos sociais e regionais das comunidades onde estão inseridos e atuam como profissionais, entre outras questões basilares. Nesse sentido, a pergunta que 


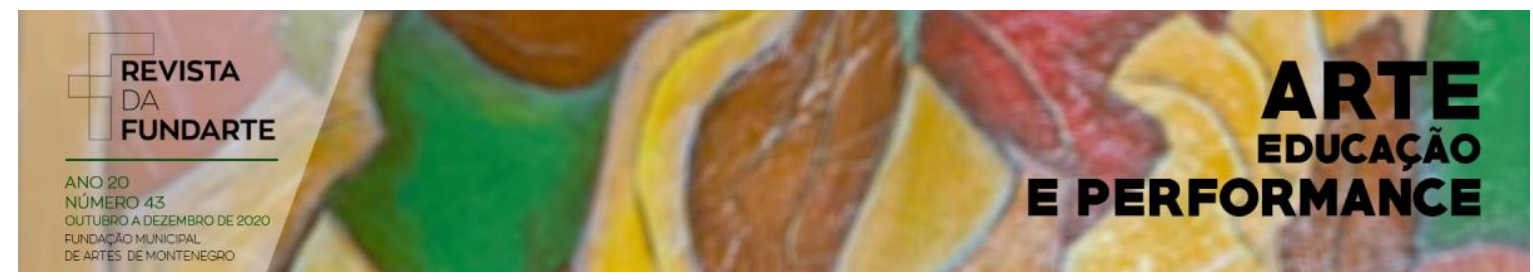

move esta pesquisa é: como se desenha a trajetória profissional dos professores de Arte da Educação Básica, da rede pública de ensino, no âmbito da Gerência de Educação/GERED 01 - São Miguel do Oeste/SC?

A disciplina de Arte se apresenta no currículo escolar, assegurada pela LDB, em seu último documento atualizado em março de 2017, que diz em seu artigo 26으, parágrafo $2^{0}$ : "O ensino da arte, especialmente em suas expressões regionais, constituirá componente curricular obrigatório da educação básica" (LDB, 1996). E ainda, em seu artigo 35-- A, que cita a arte como prática obrigatória para o ensino médio, uma vez que se encontra na BNCC, Base Nacional Comum Curricular. Mesmo assegurada, a disciplina de arte transita por mudanças e variações nas discussões governamentais, tanto federais, como estaduais e municipais.

Sabemos que a disciplina esteve em constante mudança, tanto nas leis, como nas próprias metodologias usadas ao longo dos anos. Ana Mae Barbosa (2005) procura, ao longo de sua trajetória acadêmica, esclarecer historicamente todas essas mudanças filosóficas, políticas, sociais e educacionais, pela qual o ensino das artes passou no Brasil. Sabendo das origens e do percurso, poderemos refletir sobre os processos atuais do ensino e da docência, ela diz: "com o objetivo de conscientizar o professor de Arte acerca das raízes de seus métodos, o que auxiliará a refletir acerca da atualidade e da propriedade desses métodos hoje". (Barbosa, 2005 p.12). Conhecer o percurso, entender as mudanças e escolher os métodos são algumas das condições que garantem a legitimidade da pesquisa enquanto caminho para uma reflexão ativa, a construção do conhecimento efetivada dentro da sala de aula.

Essas reflexões sobre as práticas e os desafios do professor de Arte na contemporaneidade fortalecem a compreensão de que é necessário manter um trabalho reflexivo sobre as teorias e práticas que permeiam as ações pedagógicas durante o processo de ensino e aprendizagem, assim como pensar sobre o cotidiano docente para construir, de maneira positiva, melhores condições para os alunos, para os docentes e para a educação. Assim, o presente trabalho tem como objetivo Santa Catarina. Revista da FUNDARTE. Montenegro, p.01-21, ano 20, ํㅡ 43, outubro/dezembro de 2020.

Disponível em: http://.seer.fundarte.rs.gov.br/index.php/revistadafundarte/index> 20 de dezembro de 2020. 


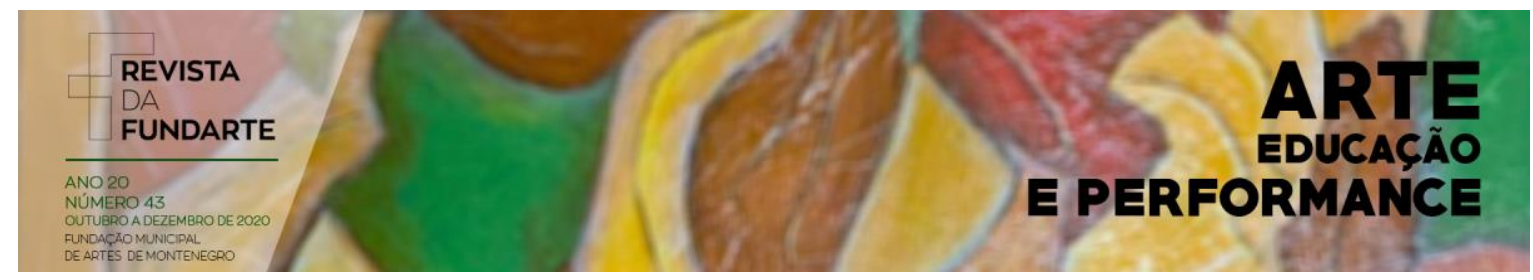

identificar o perfil profissional dos docentes de Arte, em 2017, no âmbito da GERED 01, da rede pública de ensino (municipal, estadual e federal), localizando-o nos municípios e respectivas redes de ensino, e apontando suas características sociais e profissionais.

\section{Ponto de partida}

Esta pesquisa é qualiquantitativa, envolvendo métodos quantitativos e qualitativos para a obtenção das análises que partem de atividades humanas e das experiências e vivências do grupo social para o qual a pesquisa está direcionada, numa relação direta com o cotidiano e a realidade social dos indivíduos envolvidos. Minayo (2000, p.18) afirma que "as questões da investigação estão, portanto, relacionadas a interesses e circunstâncias socialmente condicionadas. São frutos de determinada inserção no real, nele encontrando suas razões e seus objetivos".

Todo conhecimento desenvolvido e apreendido ao longo da prática educacional gera indagações e reflexões cotidianas sobre o saber pedagógico. Em uma constante busca pela compreensão e pelo aprimoramento, apontamos os primeiros caminhos metodológicos de uma investigação sobre a realidade dos professores de artes da região que compreende a Gerência de Estado da Educação/GERED 01 - São Miguel do Oeste/ Santa Catarina.

Para pensar nesse contexto de práxis educacional, iniciamos uma investigação sobre a realidade dos docentes de Arte e das aulas da disciplina em escolas públicas- Federais, Estaduais e Municipais- pertencentes ao extremo oeste catarinense, mais precisamente as escolas de Educação Básica, da região que compreende a Gerência de estado da Educação/GERED 01, localizada no município de São Miguel do Oeste. Os municípios que compõe a GERED 01, são: Barra Bonita, Bandeirante, Belmonte, Descanso, Guaraciaba, Paraíso e São Miguel do Oeste. Nessas localidades contamos com escolas estaduais, de responsabilidade da GERED e escolas públicas Municipais de responsabilidade das prefeituras desses municípios. No município de São Miguel do Oeste existe também uma escola Santa Catarina. Revista da FUNDARTE. Montenegro, p.01-21, ano 20, ํㅡ 43, outubro/dezembro de 2020.

Disponível em: http://.seer.fundarte.rs.gov.br/index.php/revistadafundarte/index> 20 de dezembro de 2020. 


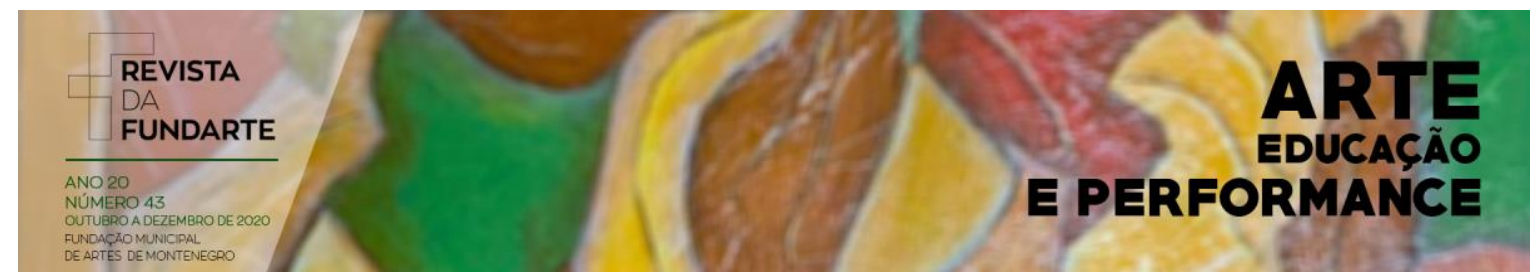

pública federal, um campus do Instituto Federal de Santa Catarina (IFSC). A instituição pública federal está vinculada ao Ministério da Educação (MEC), por meio da Secretaria de Educação Profissional e Tecnológica (SETEC).

\title{
Primeiro Momento: onde estão
}

Primeiramente, verificou-se por meio de um trabalho de campo, quem são os sujeitos da pesquisa, quantificando-os e localizando-os. Pois, segundo Bauer e Gaskell (2013), para mensurar fatos sociais precisamos categorizá-los.

\begin{abstract}
Se alguém quer saber a distribuição de cores num jardim de flores, deve primeiramente identificar o conjunto de cores que existem no jardim; somente depois disso pode-se começar a contar as flores de determinada cor. O mesmo é verdade para os fatos sociais. (BAUER E GASKELL, 2013, p. 24).
\end{abstract}

Quem são os sujeitos e onde estão inseridos? Buscamos as primeiras informações nas secretarias de Educação dos municípios de Barra Bonita, Bandeirante, Belmonte, Descanso, Guaraciaba, Paraíso, São Miguel do Oeste e na GERED 01, responsável pelas escolas estaduais.

Organizamos três mapas para a localização das primeiras informações. Verifica-se que podemos identificar, primeiramente, a localização geográfica do estado de Santa Catarina dentro do país, em seguida a região pesquisada localizada geograficamente dentro do estado e a localização dos sete municípios pertencentes à GERED 01, dentro da microrregião do extremo oeste do estado de Santa Catarina. Uma vez identificado o território, obtemos a quantidade das escolas públicas e dos professores que atuam na disciplina de Artes.

MOREIRA, Noeli. Os caminhos do ensino de arte em algumas escolas públicas do extremo oeste de Santa Catarina. Revista da FUNDARTE. Montenegro, p.01-21, ano 20, ํㅡ 43, outubro/dezembro de 2020.

Disponível em: http://.seer.fundarte.rs.gov.br/index.php/revistadafundarte/index> 20 de dezembro de 2020. 

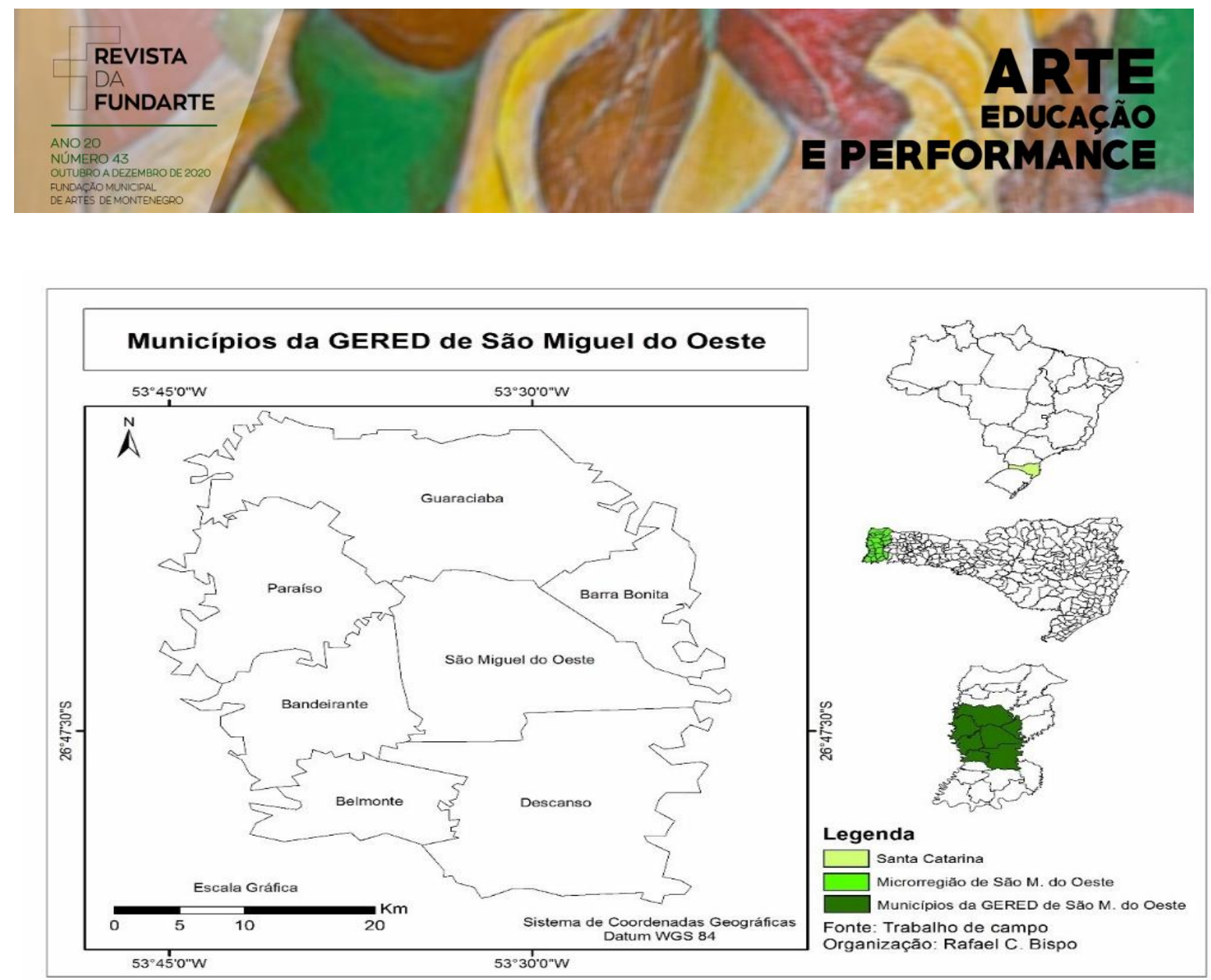

Mapa 01: localização geográfica da região pesquisada. Fonte: dados coletados pela autora e construídos a partir de informações dos vetores do IBGE $^{2}$ e da GERED 01, organizados em mapa pelo professor Rafael Bispo3.

Observamos que os sete municípios que fazem parte desta pesquisa pertencem a microrregião de São Miguel do Oeste, que fica localizada na mesorregião Oeste do estado de Santa Catarina. Nessa região existem ao todo 21 municípios.

No mapa 02 apresentamos a distribuição das escolas públicas desses municípios. Constatamos que existem 29 escolas públicas municipais, 20 escolas

\footnotetext{
2 IBGE: O Instituto Brasileiro de Geografia e Estatística, principal provedor de dados e informações do País, que atendem às necessidades dos mais diversos segmentos da sociedade civil, bem como dos órgãos das esferas governamentais federal, estadual e municipal. Disponível em: $<$ https://www.ibge.gov.br/institucional/o-ibge.html>. Acesso em 02 nov. 2018.

3 Professor Rafael Bispo: Licenciado e bacharel em Geografia pela UNESP. É mestre e doutor em Engenharia Agrícola, na área de concentração de Planejamento e Desenvolvimento Rural. Sustentável, pela Faculdade de Engenharia Agrícola/UNICAMP, com projeto na área de Sensoriamento Remoto e Geoprocessamento aplicados ao monitoramento de áreas agrícolas. Atualmente professor substituto no Instituto Federal de Santa Catarina.
}

MOREIRA, Noeli. Os caminhos do ensino de arte em algumas escolas públicas do extremo oeste de Santa Catarina. Revista da FUNDARTE. Montenegro, p.01-21, ano 20, ํㅡ 43, outubro/dezembro de 2020.

Disponível em: http://.seer.fundarte.rs.gov.br/index.php/revistadafundarte/index> 20 de dezembro de 2020. 


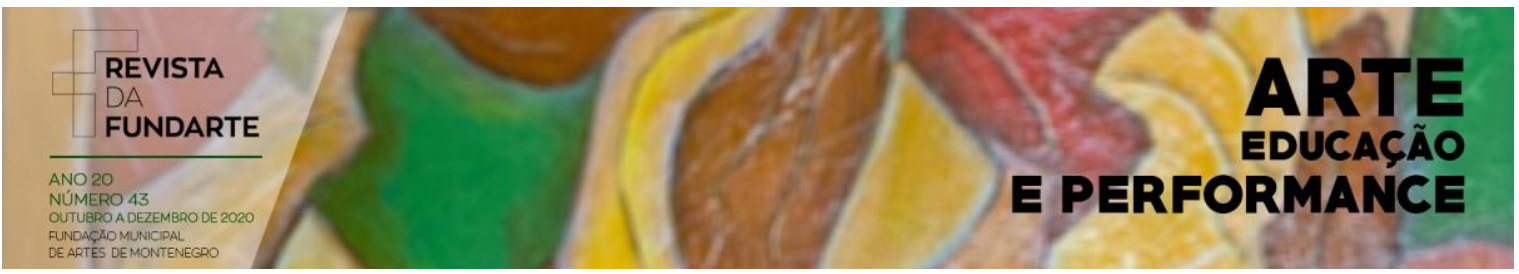

estaduais e 01 (uma) escola federal. Num total de 50 escolas, que atendem a Educação Básica.

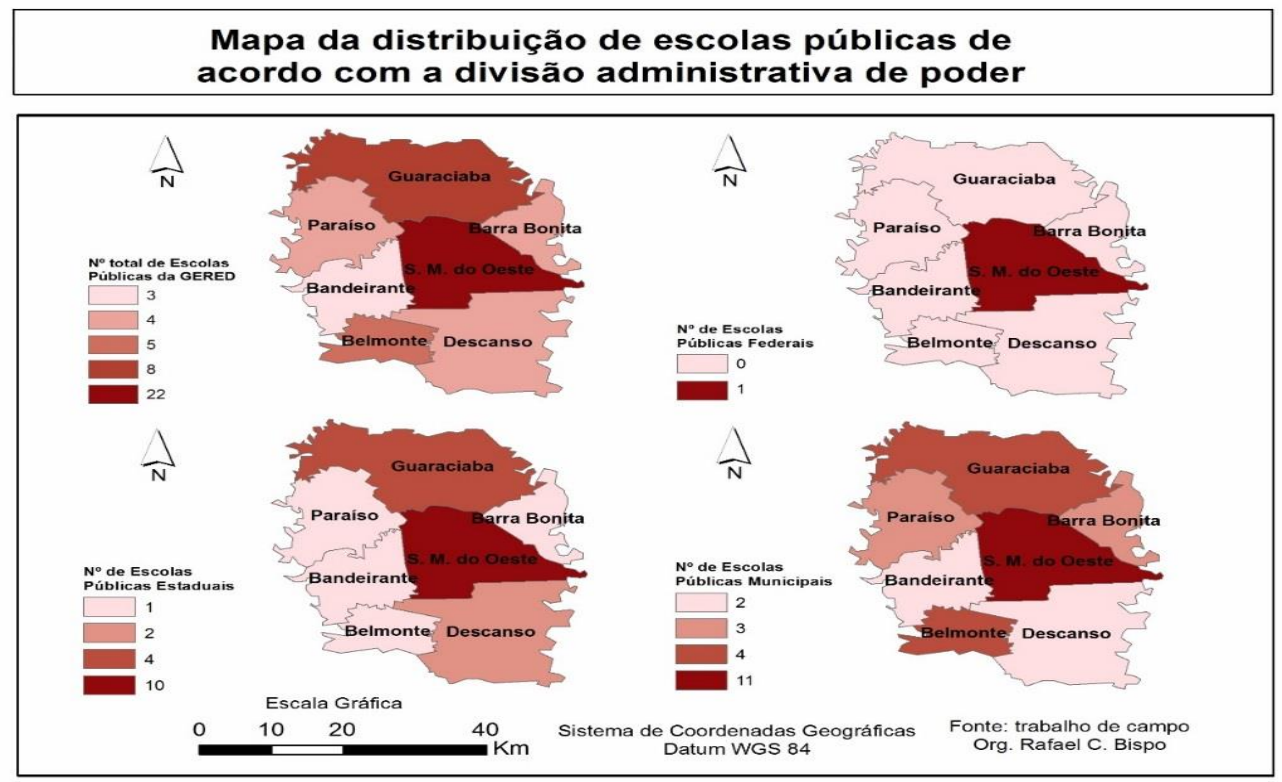

Mapa 02: distribuição das escolas públicas. Fonte: dados coletados pela autora e construídos a partir de informações dos vetores do IBGE e da GERED 01, organizados em mapa pelo professor Rafael Bispo.

E no mapa 03 apresentamos o número de professores de arte atuantes nas escolas públicas e de cada rede: federal: 01(um) professor, estadual: 26 professores e municipais: 21 professores, num total de 48 profissionais, porém alguns professores trabalham tanto na rede municipal como no estado e, ainda na rede privada. Assim o número de professores diminui do total geral, ficando em 34 docentes.

MOREIRA, Noeli. Os caminhos do ensino de arte em algumas escolas públicas do extremo oeste de Santa Catarina. Revista da FUNDARTE. Montenegro, p.01-21, ano 20, ํㅡ 43, outubro/dezembro de 2020.

Disponível em: http://.seer.fundarte.rs.gov.br/index.php/revistadafundarte/index> 20 de dezembro de 2020. 

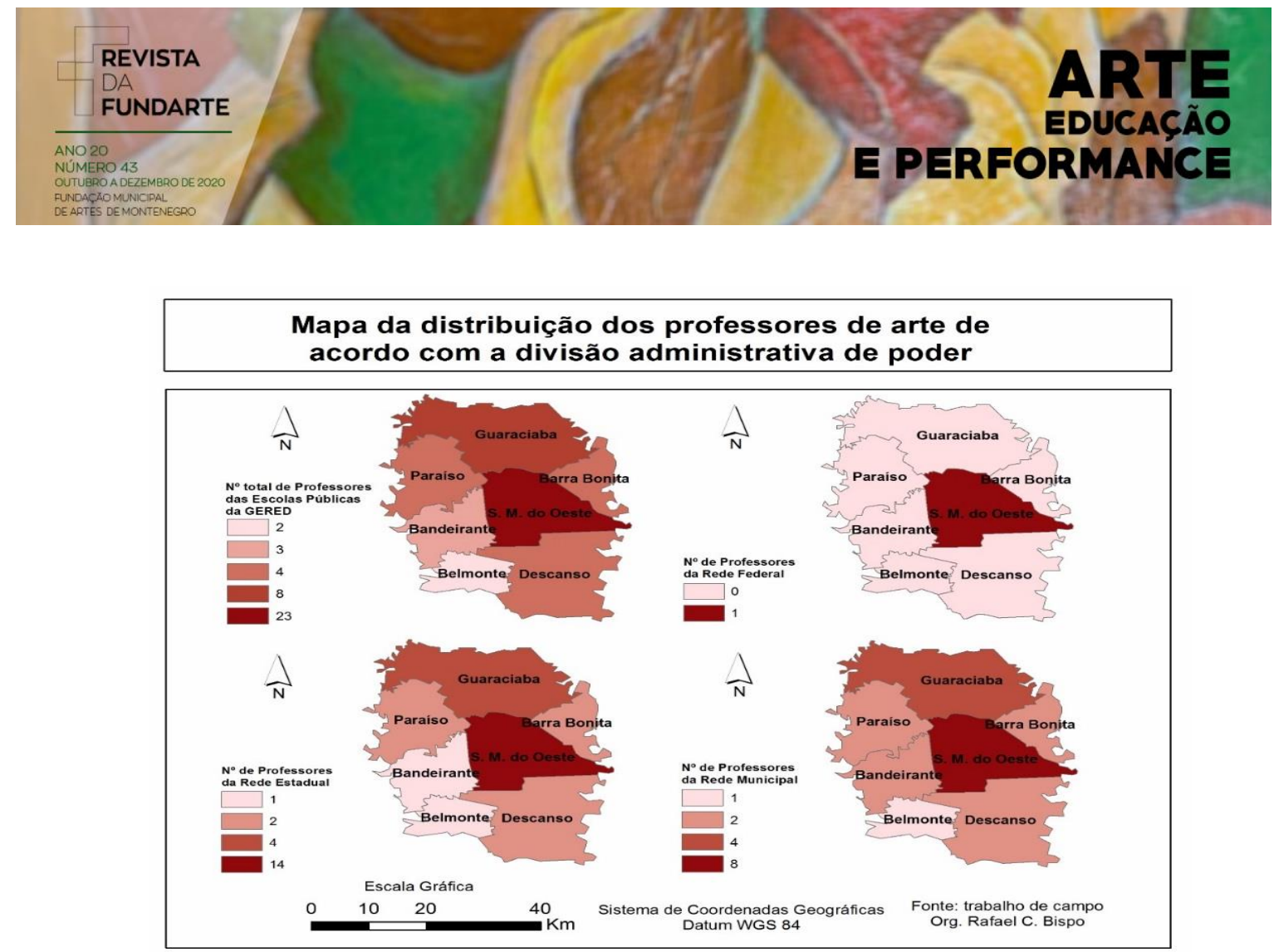

Mapa 03: distribuição do número de professores. Fonte: dados coletados pela autora e construídos a partir de informações dos vetores do IBGE e da GERED 01, organizados em mapa pelo professor

Rafael Bispo.

Para a identificação do número de escolas e professores, entrou-se em contato através de telefonemas e e-mails às Secretarias de Educação dos municípios e de visita in loco à sede da GERED 01. Obteve-se relativo êxito nesta primeira fase. Dos sete municípios, apenas um não respondeu ao levantamento, levando assim, o pesquisador ao levantamento de dados, diretamente, com professores efetivos deste município. Após as etapas dessa primeira fase de pesquisa, foram organizados os dados em mapas geográficos de identificação dos municípios, do número de escolas públicas, federais, estaduais e Municipais e o respectivo número de professores atuantes em cada rede.

\section{Segundo momento: quem são}

Para que essa pesquisa pudesse ser realizada com os professores da área de artes, se fez necessário um levantamento do perfil profissional desses professores, mais detalhadamente. Assim, optou-se pela procura de seus nomes

MOREIRA, Noeli. Os caminhos do ensino de arte em algumas escolas públicas do extremo oeste de Santa Catarina. Revista da FUNDARTE. Montenegro, p.01-21, ano 20, ํㅡ 43, outubro/dezembro de 2020.

Disponível em: http://.seer.fundarte.rs.gov.br/index.php/revistadafundarte/index> 20 de dezembro de 2020. 


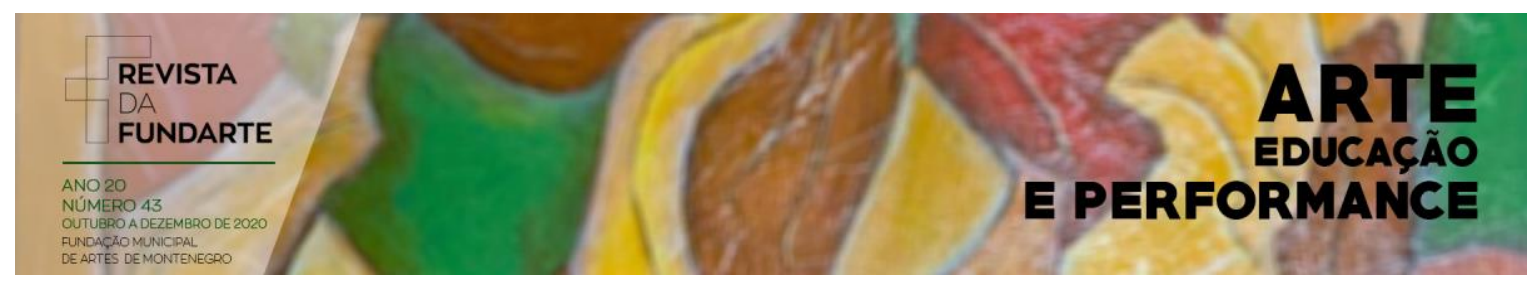

nas redes sociais e através dos números de telefones. Optamos pela entrevista estruturada, seguindo perguntas previamente estabelecidas, com a possibilidade de respostas abertas e fechadas. Numa aproximação particular e individual, nos apresentamos explicando o teor desta pesquisa, e pedimos permissão para o envio do questionário, formulado através do programa Google Drive em formulários. Esse instrumento é de fácil acesso, permitindo acompanhar as respostas através de gráficos e planilhas. Foram formuladas 13 questões de caráter pessoal e profissional, começando primeiramente, pelas questões de identificação pessoal, depois sobre as informações profissionais do magistério e de sua atuação na disciplina de Arte. No início do questionário foi feita uma apresentação escrita como ementa do questionário, em seguida a descrição das questões, que são descritas em ordem do questionário, assim distribuídas: Endereço de e-mail, Nome Completo, Sexo, Faixa etária; Tempo no exercício do magistério; Curso superior realizado, com a identificação da instituição e ano de finalização; Rede de ensino onde trabalha; de qual o município e o tipo de contratação; Curso de pós graduação indicando o nome do curso, instituição e ano de conclusão; Curso de Formação Continuada, indicando o nome do último curso realizado; instituição e ano de conclusão; e se faz alguma produção artística fora do espaço escolar: como artesanato, produção para exposição, desenvolvimento de técnica ou pesquisa plástica.

Dos 34 professores das redes estaduais e municipais, responderam ao questionário 24 professores. Entre os 10 professores que não responderam ao questionário, 02 professores não foram encontrados, nem por telefone e nem pelas redes sociais, 1 professor não visualizou a solicitação pela rede social, sendo que o único contato existente era através da rede. Outros 02 professores tiveram acesso ao questionário, mas alegaram que não conseguiram mandar as informações pelo programa Google Drive de formulários, e 05 professores tiveram acesso, mas não responderam alegando outros motivos. Após as etapas de coleta e verificação, os dados foram tabulados em gráficos para análise.

MOREIRA, Noeli. Os caminhos do ensino de arte em algumas escolas públicas do extremo oeste de Santa Catarina. Revista da FUNDARTE. Montenegro, p.01-21, ano 20, ํㅡ 43, outubro/dezembro de 2020.

Disponível em: http://.seer.fundarte.rs.gov.br/index.php/revistadafundarte/index> 20 de dezembro de 2020. 


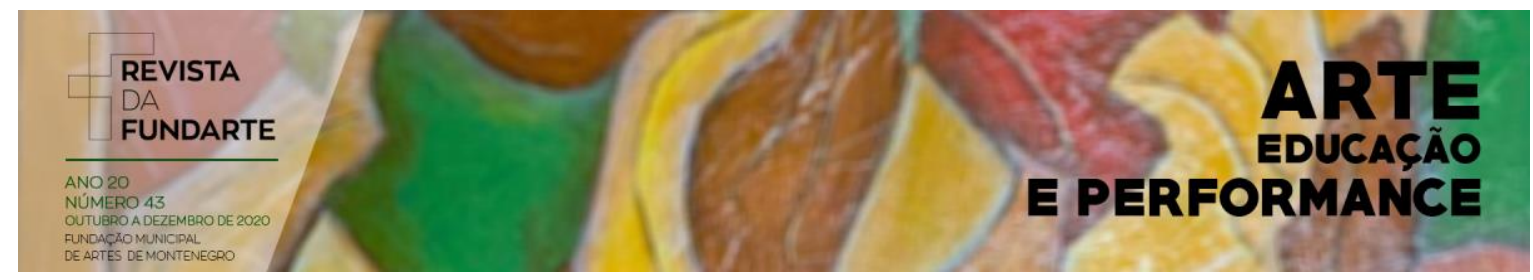

Apresentamos os resultados desta coleta de dados e alguns gráficos mais relevantes, caracterizando a primeira representação para o andamento desta pesquisa:

\section{1- Dados sobre o sexo:}

Dos 24 professores entrevistados, 01 é homem e o restante, 23 são mulheres. A discussão desta pesquisa não é apenas sobre o levantamento quantitativo do sexo no magistério, mas com essa informação verificamos uma grande diferença e constatamos que a profissão ainda é essencialmente feminina. Comparando nosso percentual com as análises do censo escolar da educação básica 2018, verificamos que a docência tem seu maior número entre as mulheres. Conforme as análises de Carvalho (2018), o perfil dos professores da área básica é predominantemente feminino, porém conforme a etapa do ensino esse percentual vai mudando:

Segundo estudo exploratório realizado pelo Instituto Nacional de Estudos e Pesquisas Educacionais Anísio Teixeira (Brasil. Inep, 2009), apesar de, no cômputo geral, a maioria dos professores em regência de classe serem mulheres, esse perfil de predominância vai-se alterando à medida que progridem as etapas de ensino, ou seja, predominância marcadamente feminina no ensino infantil e anos iniciais do ensino fundamental, com crescimento gradual da participação masculina nas etapas finais. (CARVALHO, 2018, p. 16).

Fatores histórico-sociais determinam a escolha desta profissão por mulheres. Em uma pesquisa elaborada por (Oliveira, 2004), vários são os fatores dessa escolha no âmbito da realidade brasileira, apontando questões desde 0 ano de 1827, onde a mulher adquire o direito à educação, continuando na história com alterações filosóficas, sociais, educacionais e trabalhistas, até os nossos dias. Entre elas, a autora cita a concepção que uma vez a mulher exercendo a profissão docente, estaria exercendo também a maternidade e um controle também da sua sexualidade, já que o ambiente compartilhado com crianças, não traria os perigos do mundo. Ou uma vez que a mulher era educada para servir, ela se insere no mercado de trabalho, passando a ganhar menos, uma operária, representando mão-de-obra Santa Catarina. Revista da FUNDARTE. Montenegro, p.01-21, ano 20, ํㅡ 43, outubro/dezembro de 2020.

Disponível em: http://.seer.fundarte.rs.gov.br/index.php/revistadafundarte/index> 20 de dezembro de 2020. 


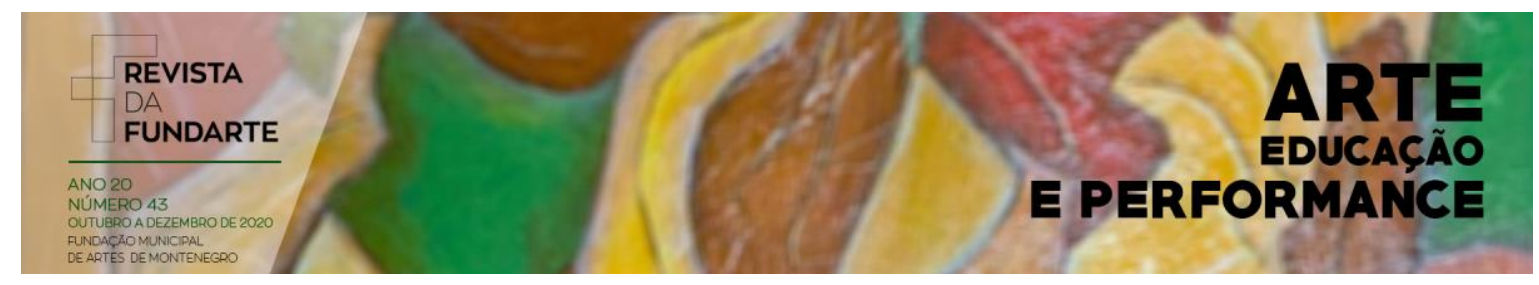

barata. Assim esse movimento oportuniza aos homens o abandono da docência e procuram algo mais rentável para o sustento da família. Podemos dizer com esses exemplos, que os dados sobre o sexo demonstrados nas pesquisas sobre a docência, feminizam a profissão docente, resultados de construções sociais patriarcais, que foram modificando ao longo de nossa história, onde hoje colhemos seus frutos positivos e negativos, mas que ainda requer um estudo mais aprofundado sobre a questão.

2- Faixa etária:

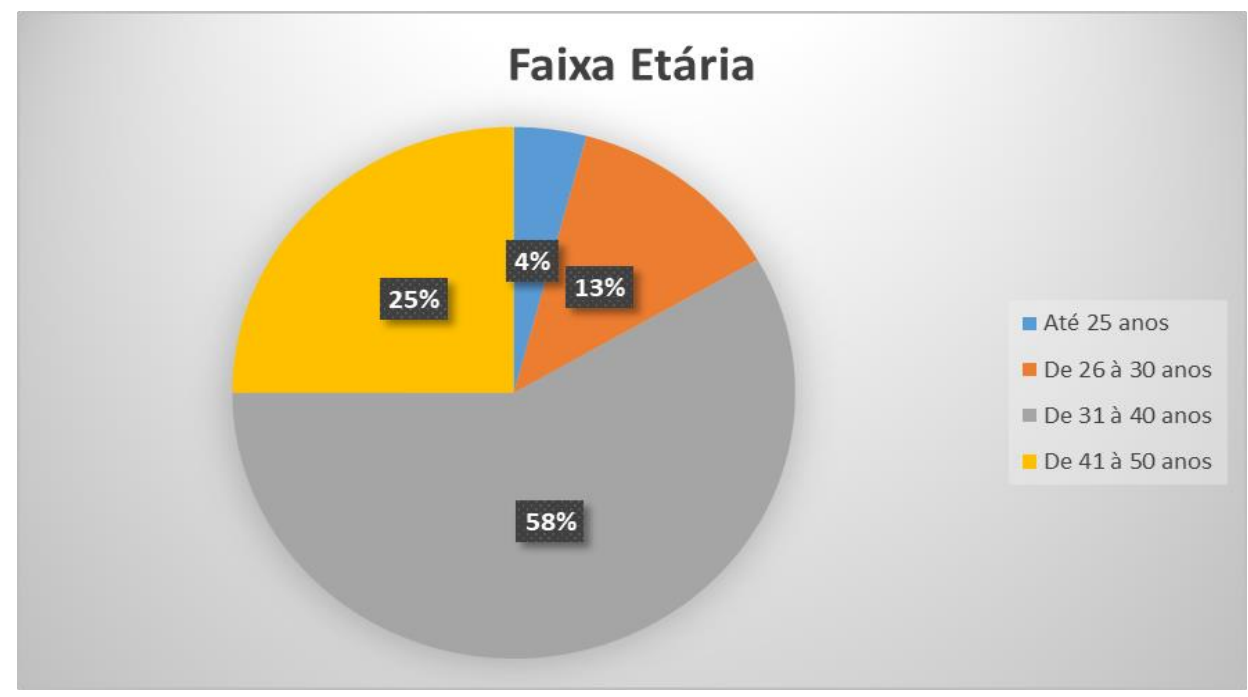

Gráfico 01. Fonte: dados coletados pela autora através do questionário online e disponíveis nos formulários do docs.google.com/forms.

A questão da faixa etária é diversa entre os entrevistados, porém é predominante os professores que tem entre 31 a 40 anos, sendo que apenas 1 professor tem menos de 25 anos. Este gráfico mostra a semelhança com o censo escolar de 2018. Carvalho (2018), comenta:

Fica evidente [...] a tendência de envelhecimento desses profissionais ao longo dos anos, com médias etárias em torno de 40 anos em 2017 para todas as etapas de ensino. Em 2009 existiam 271.143 professores com idade igual ou maior do que 50 anos (cerca de 15\% dos professores); em 2017 esse número era de 440.730 (21\%). São professores mais

MOREIRA, Noeli. Os caminhos do ensino de arte em algumas escolas públicas do extremo oeste de Santa Catarina. Revista da FUNDARTE. Montenegro, p.01-21, ano 20, ํㅡ 43, outubro/dezembro de 2020.

Disponível em: http://.seer.fundarte.rs.gov.br/index.php/revistadafundarte/index> 20 de dezembro de 2020. 


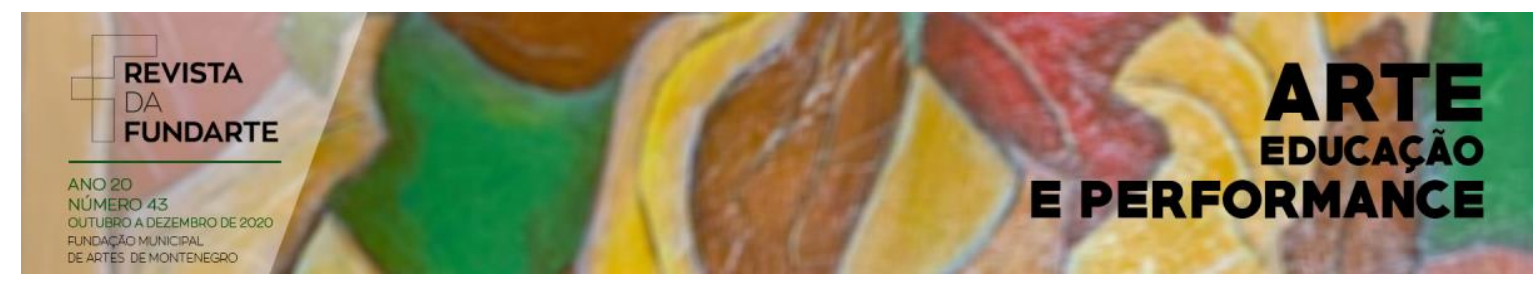

experientes, mas que estão se aproximando do tempo de aposentadoria e com possibilidade de saírem do sistema. (CARVALHO, 2018, p. 31).

A entrada de jovens na profissão é menor que a oferta de postos de trabalho. Observamos também que comparando com os dados do tempo de magistério, os professores mais novos em idade, são também novos em tempo de sala de aula. Os professores estão envelhecendo, corremos o risco de ausência de professores com formação adequada para assumirem futuramente as vagas daqueles profissionais que irão se aposentando. Salienta Carvalho (2018): "[...] o fluxo dos professores ao longo da carreira não é uniforme: professores mais novos podem estar abandonando a carreira após certa experiência, e professores mais antigos, mais estáveis, estão se aproximando da aposentadoria".

A média de faixa etária da região pesquisada equipara-se com a média nacional. Saliento que o censo escolar apresentado pelo MEC, não separa nestas questões as disciplinas separadamente, mas um total geral dos dados da docência, comparando-os também ao nível de formação acadêmica.

3- Tempo de magistério:

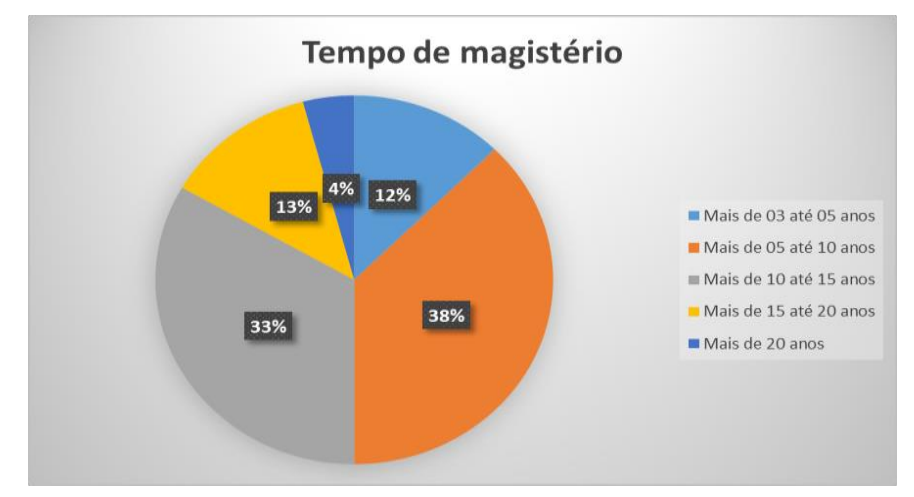

Gráfico 02. Fonte: dados coletados pela autora através do questionário online e disponíveis nos formulários do docs.google.com/forms.

O tempo de serviço nas atividades do magistério é semelhante, pode-se verificar que a maioria, $71 \%$, exerce suas funções entre 10 a 20 anos. Apenas um professor tem menos de 5 anos de exercício. Professores que trabalham há mais

MOREIRA, Noeli. Os caminhos do ensino de arte em algumas escolas públicas do extremo oeste de Santa Catarina. Revista da FUNDARTE. Montenegro, p.01-21, ano 20, ํㅡ 43, outubro/dezembro de 2020.

Disponível em: http://.seer.fundarte.rs.gov.br/index.php/revistadafundarte/index> 20 de dezembro de 2020. 


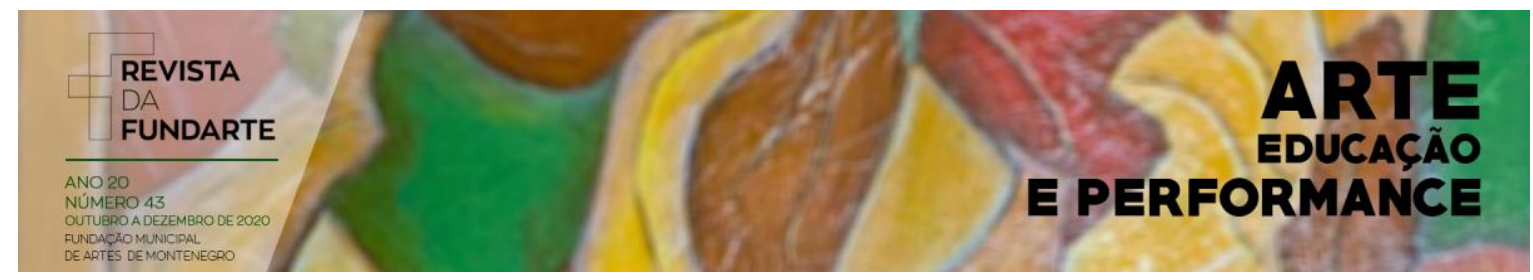

tempo, poderão perceber as mudanças na estrutura e na metodologia da disciplina ao longo dos anos. Essas mudanças poderão estar presentes em seus métodos dentro da sala de aula, de maneira positiva ou não. Além das mudanças na disciplina, a construção do conhecimento também é fator determinante para modificações na maneira de viver. Podemos citar como exemplo, a evolução da tecnologia nestes últimos 20 anos, que vai repercutir também, dentro da sala de aula e nos métodos usados pelos professores. As análises da metodologia poderão ser feitas no decorrer da pesquisa, quando, após a escolha dos sujeitos pesquisados, a observação direta será referência para futuras reflexões da realidade docente.

\section{4- Formação de curso superior:}

Constatamos que todos têm curso superior na área de Artes. O que muda é a nomenclatura entre Educação Artística, 75\% dos professores e Artes Visuais, 25\% dos entrevistados. Houve uma alteração da nomenclatura no Diário Oficial da União publicado em 24/07/2008, com as Diretrizes Curriculares Nacionais do Curso de Graduação em Artes Visuais, para bacharelado e licenciatura. Na universidade do oeste de Santa Catarina UNOESC, principal formadora da região, a mudança ocorreu no ingresso da turma em 2009, passando de licenciatura em Educação Artística, para licenciatura em Artes Visuais.

A realidade local de formação específica na área de Arte não é parecida com a realidade nacional. Conforme Censo Escolar da Educação Básica 2018, através do documento Resumo Técnico divulgado pelo INEP/Instituto Nacional de Estudos e Pesquisas Educacionais Anísio Teixeira, em janeiro de 2019, os docentes que atuam nos anos iniciais do ensino fundamental na disciplina de artes perfazem $62,7 \%$; os docentes que atuam nos anos finais do ensino fundamental, são apenas $35,6 \%$; e os docentes do ensino médio, um total de $47,1 \%$. Diferentemente do percentual de $100 \%$ com formação específica, no caso desta região pesquisada, que se dá pela oferta do curso na universidade local, garantindo o acesso aos estudantes da região e consequentemente, a sua formação na área. 


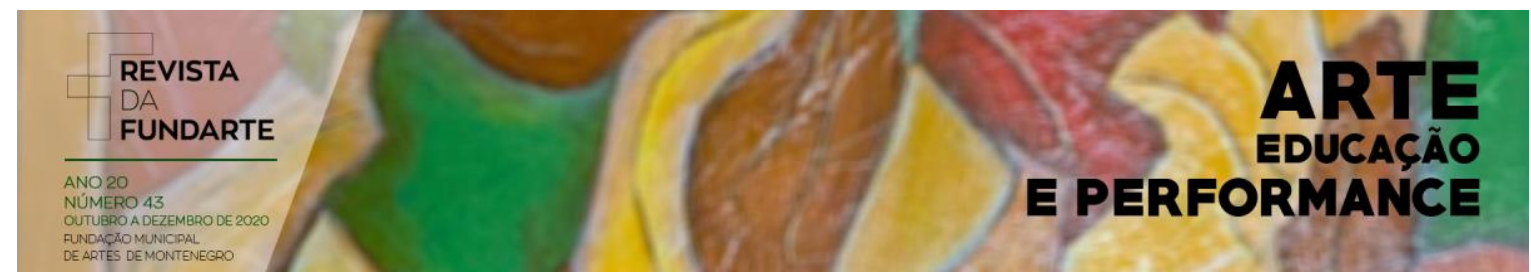

5- Instituição de Formação Superior:

Outra análise decorrente do questionário, são as instituições por onde passaram a maioria dos professores. Por estarmos afastados dos grandes centros urbanos, 22 dos professores entrevistados tem sua formação na UNOESC, que ofereceu a licenciatura específica durante 15 anos na região, entre os anos de 1998 até 2012. A última turma teve seu encerramento em 2015. Tanto os cursos presenciais normais de quatro anos, como os com parcerias, como o programa Magister $^{4}$, em parceria com o governo do estado de Santa Catarina, e com o programa da Plataforma Freire ${ }^{5}$, em parceria com a CAPES.

Um dos professores é formado pela FURB (Universidade Regional de Blumenau), pois veio para a região acompanhando sua família após sua formação, e outro professor com formação pela UNAR (Centro Universitário de Araras "Dr. Edmundo Ulson"), no estado de São Paulo, que oferece a graduação em licenciatura em Artes Visuais à distância.

6- Rede de ensino onde trabalham:

\footnotetext{
${ }^{4}$ Programa em parceria estabelecida entre o Governo do Estado e Instituições de Educação Superior (IES) sediadas em Santa Catarina e autorizado pelo CEE/SC em 1996.

5 Criada pelo Ministério da Educação é um sistema informatizado e destinado a formação de professores da educação básica pública, no exercício do magistério, nas instituições públicas de ensino superior.
}

MOREIRA, Noeli. Os caminhos do ensino de arte em algumas escolas públicas do extremo oeste de Santa Catarina. Revista da FUNDARTE. Montenegro, p.01-21, ano 20, ํㅡ 43, outubro/dezembro de 2020.

Disponível em: http://.seer.fundarte.rs.gov.br/index.php/revistadafundarte/index> 20 de dezembro de 2020. 

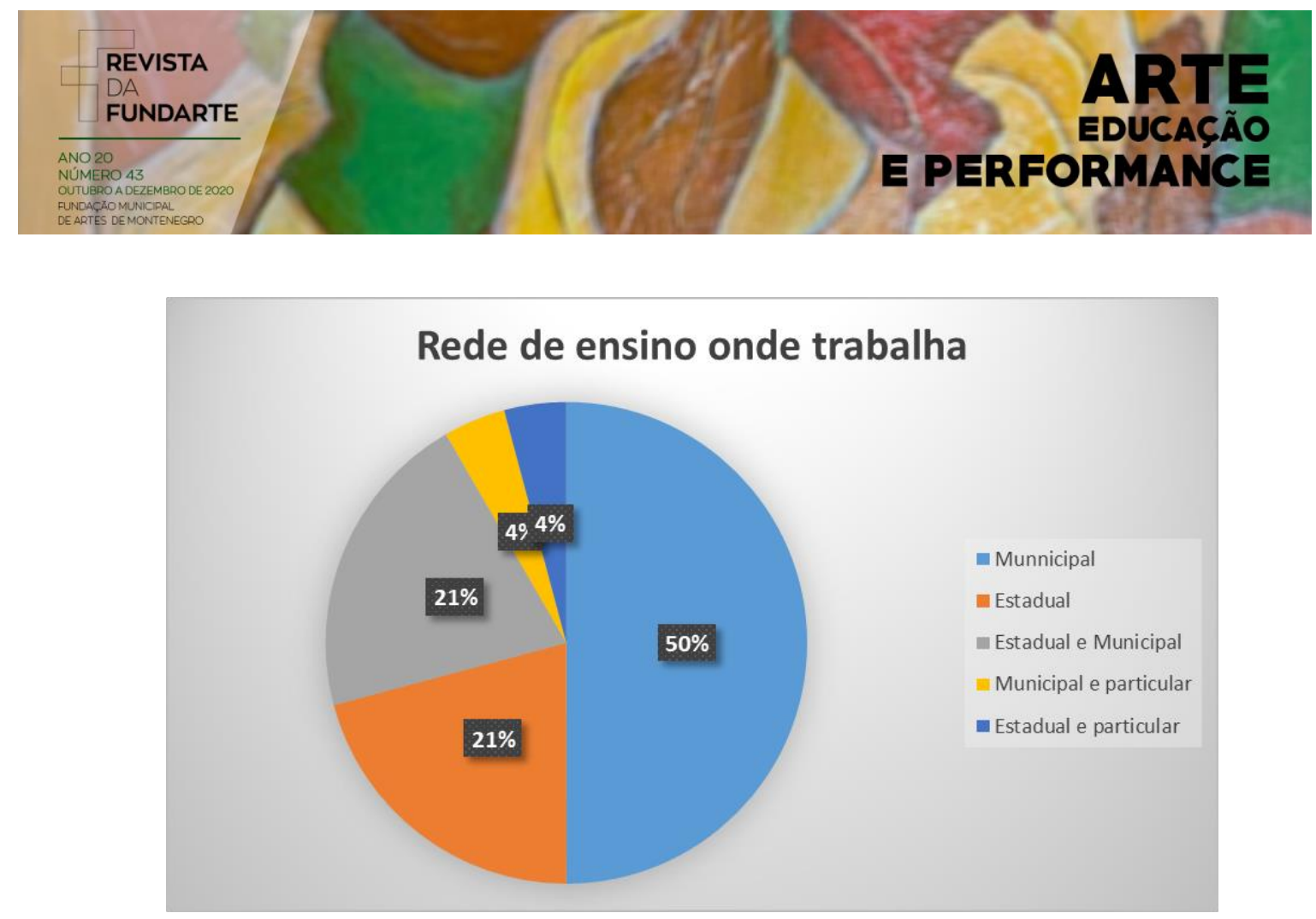

Gráfico 03. Fonte: dados coletados pela autora através do questionário online e disponíveis nos formulários do docs.google.com/forms.

Os professores entrevistados trabalham em escolas públicas estaduais e municipais, a grande maioria, num total de 12, está na rede municipal. Apenas 05 trabalham exclusivamente na rede estadual e 05 professores trabalham, tanto na rede estadual como municipal e ainda, 02 professores entrevistados trabalham para as redes públicas de ensino, mas complementam sua carga horária com escolas privadas na região.

\section{7- A forma de contratação:}

Uma parcela considerável dos professores é efetiva em seus locais de trabalho, que somam um total de 16 professores. Dentro do regime de contratação temporária, temos a quantia de 06 professores e ainda temos 2 professores, que trabalham numa rede como efetivos, e em outra rede como contratados. Este resultado reforça os dados coletados entre a idade e o tempo de magistério, pois fica evidente a estabilidade dos professores que se dedicam à profissão por um determinado período. A possibilidade de estabilidade no setor público influencia para a escolha da carreira e para a permanência, somando-se a esses fatores, também Santa Catarina. Revista da FUNDARTE. Montenegro, p.01-21, ano 20, ํㅡ 43, outubro/dezembro de 2020.

Disponível em: http://.seer.fundarte.rs.gov.br/index.php/revistadafundarte/index> 20 de dezembro de 2020. 


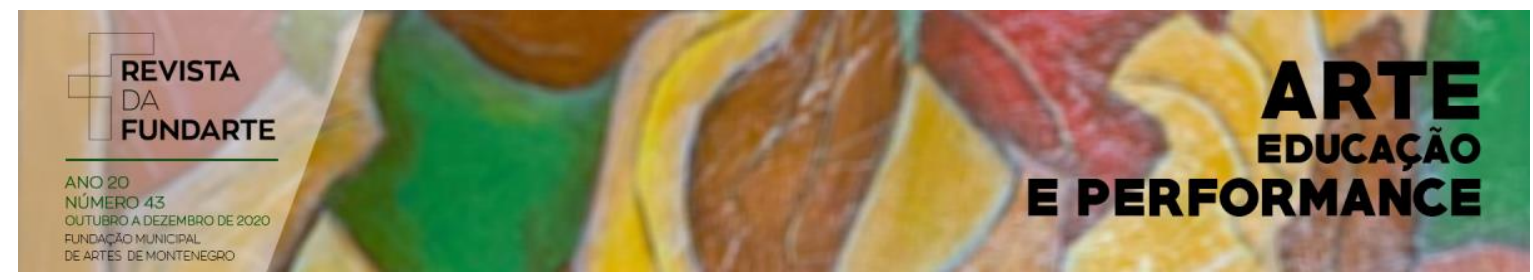

os projetos de vida, entre as experiências e as expectativas, gerando inclusive, a busca pelo aprimoramento da profissão.

8- Curso de pós-graduação, especialização por área:

Constatamos que a maioria dos professores tem cursos de especialização, na área específica de sua graduação, os quais são 18 professores. Os cursos de pós-graduação em Artes são diversos, transitando nas linguagens de Artes Visuais, Dança, Música e Teatro. Outros 03 professores na área da educação em EJA, Séries iniciais e gestão pública, e 01 (um) professor na área de psicologia, num total de 22 professores com o curso de pós-graduação. A maioria das instituições que ofertam os cursos de pós-graduação é da região do Oeste de Santa Catarina: como a UNOESC, CELER Faculdades, FAI (Faculdades de Itapiranga) e o IFSC, mas observamos a presença da Universidade do Rio Grande do Sul, URI (Universidade Regional Integrada do Alto Uruguai e das Missões), bem como cursos ofertados à distância por outras instituições. Apenas 02 professores ainda não têm especialização.

9- Cursos de formação continuada:

A formação continuada também foi averiguada durante a coleta de dados. Dentre os 24 professores entrevistados, 18 destes já fizeram cursos, 03 nunca fizeram e 03 estavam fazendo. Observamos que nem sempre os cursos realizados pelos professores têm sido na área específica de arte, percorrendo por variados assuntos educacionais. Coutinho (2003) salienta que:

A formação do professor se intensifica à medida que ele se defronta com as situações reais de ensino e aprendizagem. [...] O professor de Arte precisa sair da sala de aula e interagir com os espaços culturais, museus, bibliotecas, e outras instituições que produzem e veiculam os bens culturais. Precisa se conectar às redes de informação. (COUTINHO 2003, p. 158).

Deve-se olhar para a área continuamente, ampliando o conhecimento específico. A maioria dos professores de Arte desta região apresenta uma MOREIRA, Noeli. Os caminhos do ensino de arte em algumas escolas públicas do extremo oeste de Santa Catarina. Revista da FUNDARTE. Montenegro, p.01-21, ano 20, ํㅡ 43, outubro/dezembro de 2020.

Disponível em: http://.seer.fundarte.rs.gov.br/index.php/revistadafundarte/index> 20 de dezembro de 2020. 


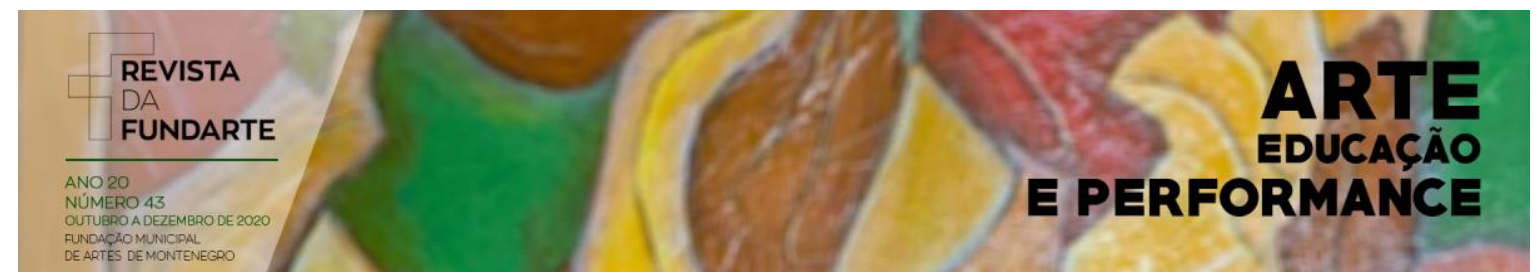

continuidade em sua aprendizagem. O mundo está em constante movimento e a construção do conhecimento requer uma atenção, quando se trata da formação docente. Parece evidente que a formação continuada é necessária, pois determina novas condições de trabalho e novas oportunidades para a reflexão e para as mudanças pedagógicas no espaço educacional, Verdinelle (2007). O professor constrói diariamente suas reflexões no ato de ensinar e nas suas práticas, ao longo de sua vida profissional. Conhecer, refletir e agir, são movimentos circulares no cotidiano docente.

10-Algum tipo de produção artística fora do espaço escolar:

As possibilidades do fazer sensível, aliadas ao pensamento estético e criativo, é uma constante na disciplina de Arte, e consequentemente na ação do professor. Cria-se métodos e instrumentos conhecendo as realidades do passado e do presente, vislumbrando possibilidades criativas para o futuro. Assim, a última pergunta do questionário é sobre a produção artística do professor de Arte. Constatamos que 09 professores não costumam criar fora do espaço escolar, e que 15 professores fazem atividades variadas fora do espaço escolar. As atividades apontadas por eles compreendem produções artísticas em fotografia, desenhos, pinturas, origamis, exposições externas, teatro, modelagem em biscuit, bordados e artesanatos diversos. Alguns criam para desenvolvimento de técnicas e aprimoramento, refletindo sobre o seu planejamento para as aulas, outros para complementação do orçamento familiar, e outros para o desenvolvimento artístico reflexivo, através de exposições fora do espaço educacional.

Com efeito faz-se necessária a apresentação dos meus questionamentos sobre o cotidiano de ser professor de Arte. Será que criar experiências artísticas, gerando conexões entre o que conhece, observa e depois, materializando-as, através do exercício manual, fora do espaço educacional institucionalizado, contribui na sua tarefa de ensinar? Com tantas responsabilidades na escola, o professor ainda precisa ocupar-se na tarefa de criar fora da escola? A ação docente não é um Santa Catarina. Revista da FUNDARTE. Montenegro, p.01-21, ano 20, ํㅡ 43, outubro/dezembro de 2020.

Disponível em: http://.seer.fundarte.rs.gov.br/index.php/revistadafundarte/index> 20 de dezembro de 2020. 


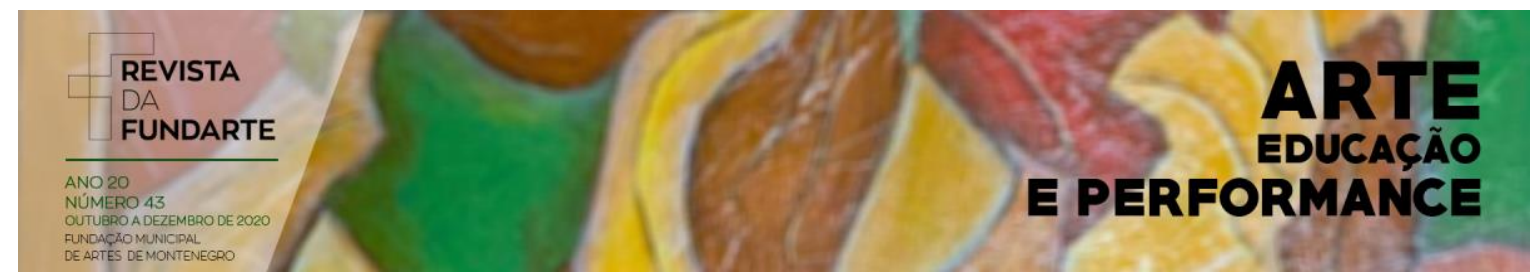

ato criativo? Um professor que cria possibilidades de criação, dentro e fora da escola, é um professor-artista? Segundo Capra e Loponte, (2016):

\begin{abstract}
À ideia de que o artista dá vida à obra de arte, corresponde a de que o professor-artista dá vida à sua prática (obra) pedagógica e cria porque tem uma necessidade vital de criar. Sendo talentosos e criadores, conseguem lidar com os problemas que ocorrem em suas atividades, situação própria de uso de seus talentos para, por exemplo, sistematizar artefatos para o ensino, criar as manobras necessárias para a compreensão das particularidades das turmas, conectar os alunos com as teorias. (CAPRA; LOPONTE, 2016, p.3).
\end{abstract}

Encontrei algumas respostas, tanto nas leituras como no cotidiano complexo dos professores pesquisados, o que contribui para os pensamentos sobre a prática pedagógica, para o conhecimento específico artístico e para a valorização da ação dos professores e da disciplina de Arte.

\title{
Chegada: considerações parciais
}

Conhecer o cotidiano educacional do entorno é o ponto de partida para a organização e o aprimoramento de toda a pesquisa. Os dados resultantes do questionário respondido pelos professores mostram fatores que ajudam nas ações de ensino e aprendizagem, nas escolas públicas desta região. Como pontos positivos, reforço a informação sobre a formação específica, ficando em 100\% entre os professores pesquisados. A busca por aprimoramento profissional, buscando a melhoria, fato este que agrega subsídios de atualização educacional, incrementando as relações entre o ensino e aprendizagem dentro da sala de aula, bem como a efetivação, de certa forma motiva a permanência na profissão e nas escolas públicas.

Como vimos, algumas questões são relevantes para esta investigação sobre as práticas da docência. Temos um conjunto de ações pertinentes à função docente, que certamente, aparecerá nas futuras pesquisas. Entre elas citamos à formação inicial e continuada do professor, à sua atuação nos espaços de formação 


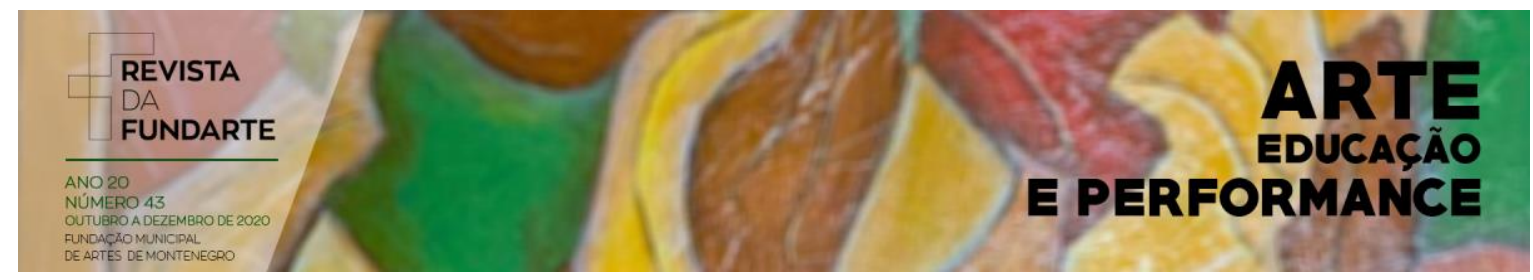

institucionalizados ou não, o seu entendimento dos processos artísticos, e de que forma isso é estimulado e desenvolvido dentro e fora da escola.

Nesse sentido, repensar o cotidiano de ser professor, traz inquietações à minha prática pedagógica. Através da continuidade da pesquisa, existe a possibilidade de vislumbrar respostas satisfatórias ao desejo de valorização da disciplina e da atuação dos professores pesquisados. O caminho das narrativas de formação e a história de vida de professores, tornam as reflexões intrínsecas ao meu cotidiano, o olhar volta-se também para dentro, ressignificando a minha atuação, enquanto docente de escola pública.

\section{Referências:}

BARBoSA. Ana Mae T. B. Arte-educação no Brasil. São Paulo: Perspectiva, 2005.

BAUER. Martin W.; GASKELL. George. Pesquisa qualitativa com texto, imagem e som: um manual prático. Petrópolis: Vozes, 2013.

CAPRA. Carmen Lúcia; LOPONTE. Luciana Gruppelli. Ditos sobre professor-artista. Reunião Científica Regional da ANPED.UFPR, Curitiba, 2016.

CARVALHO. Maria Regina Viveiros de. Perfil do professor da educação básica. Brasília, DF: Instituto Nacional de Estudos e Pesquisas Educacionais Anísio Teixeira, 2018.

FREIRE, Paulo. Pedagogia da autonomia: saberes necessários à prática educativa. São Paulo: Paz e Terra, 1996.

INEP. Instituto Nacional de Estudos e Pesquisas Educacionais Anísio Teixeira. Resumo Técnico: Censo da Educação Básica 2018 [recurso eletrônico]. - Brasília: Instituto Nacional de Estudos e Pesquisas Educacionais Anísio Teixeira, 2019. Acesso em 06/03/2019.

MINAYO, Maria Cecília de Souza. Pesquisa Social, teoria, método e criatividade. Petrópolis, RJ: Vozes, 1994.

OLIVEIRA, Vânia Fortes de. Magistério: profissão Feminina? In: OLIVEIRA. Valeska Fortes de. (org.). Imagens de professor: significações do trabalho docente. Ijuí: Unijuí, 2004. Santa Catarina. Revista da FUNDARTE. Montenegro, p.01-21, ano 20, ํㅡ 43, outubro/dezembro de 2020.

Disponível em: http://.seer.fundarte.rs.gov.br/index.php/revistadafundarte/index> 20 de dezembro de 2020. 


\section{ARTE

VERDINELLI, Marilsa Maria. Formação continuada de professores do ensino fundamental subsidiada pela pedagogia histórico crítica e teoria histórico-cultural. Dissertação de Mestrado. UNIVERSIDADE ESTADUAL DE MARINGÁ, 2007.

http://portal.mec.gov.br/dmdocuments/estudoprofessor.pdf, em 06/02/2018 https:portal.mec.gov.br/cne/arquivos/pdf/2007/pces280_07.pdf em 07/02/2018.

http://portal.mec.gov.br/component/content/article/211-noticias, em 11 de março de 2019.

https:www.planalto.gov.br/ccivil_03/leis//9394.htm, em 23/01/2018.

https://www.unar.edu.br/copia-administracao-ead, em 30/01/2018.

MOREIRA, Noeli. Os caminhos do ensino de arte em algumas escolas públicas do extremo oeste de Santa Catarina. Revista da FUNDARTE. Montenegro, p.01-21, ano 20, ํㅡ 43, outubro/dezembro de 2020.

Disponível em: http://.seer.fundarte.rs.gov.br/index.php/revistadafundarte/index> 20 de dezembro de 2020. 